This is an author produced version of a paper published in Science of The Total Environment.

This paper has been peer-reviewed and is proof-corrected, but does not include the journal pagination.

Citation for the published paper:

Stefan B. Bengtsson, Annemieke I. Gärdenäs, Jan Eriksson, Mykhailo Vinichuk, Klas Rosén. (2014) Interception and retention of wet-deposited radiocaesium and radiostrontium on a ley mixture of grass and clover. Science of The Total Environment. Volume: 497-498, pp 412-419. http://dx.doi.org/10.1016/j.scitotenv.2014.07.099.

Access to the published version may require journal subscription. Published with permission from: Elsevier Ltd..

Standard set statement from the publisher:

"NOTICE: this is the author's version of a work that was accepted for publication in $<$ Science of The Total Environment $>$. Changes resulting from the publishing process, such as peer review, editing, corrections, structural formatting, and other quality control mechanisms may not be reflected in this document. Changes may have been made to this work since it was submitted for publication. A definitive version was subsequently published in SCIENCE OF THE TOTAL ENVIRONMENT, [VOL 497-498 (2014)] DOI\#10.1016/j.scitotenv.2014.07.099"

Epsilon Open Archive http://epsilon.slu.se 


\title{
Interception and Retention of Wet-deposited Radiocaesium and Radiostrontium on a Ley Mixture of Grass and Clover
}

\author{
Stefan B. Bengtsson ${ }^{\mathrm{a}^{*}}$, Annemieke I. Gärdenäs ${ }^{\mathrm{a}}$, Jan Eriksson ${ }^{\mathrm{a}}$, Mykhailo Vinichuk ${ }^{\mathrm{b}}$ and Klas Rosén ${ }^{\mathrm{a}}$ \\ ${ }^{a}$ Swedish University of Agricultural Sciences, Department of Soil and Environment, P.O. Box 7014, SE-75007, \\ Uppsala, Sweden

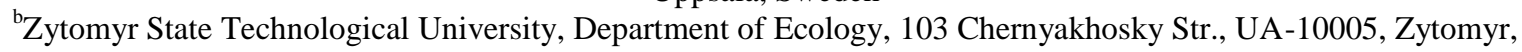 \\ Ukraine \\ *Corresponding author: E-mail: stefan.bengtsson@ @ slu.se
}

\begin{abstract}
The aims of this study were to assess the potential radioactive contamination of fodder in the case of accidental radionuclide fallout, and to analyse the relationship between interception and retention of radionuclides as a function of biomass and Leaf Area Index (LAI). The interception and the retention of wet deposited ${ }^{134} \mathrm{Cs}$ and ${ }^{85} \mathrm{Sr}$ in ley (a mixture of grass and clover) were measured after artificial wet deposition in a field train in Uppsala (eastern central Sweden). The field trial had a randomised block design with three replicates. ${ }^{134} \mathrm{Cs}$ and ${ }^{85} \mathrm{Sr}$ were deposited at six different growth stages during two growing seasons (20101 and 2011) using a rainfall simulator. The biomass was sampled in the centre of each parcel 2 to $3 \mathrm{~h}$ after deposition and at later growth stages ( 1 to 5 ) during the growing season. The above ground biomass and LAI were measured as well.

The interception of radionuclides by the ley was largest at the late growth stages; the spike and tassel/flowering (code 5:6) in the $1^{\text {st }}$ year, and at flowering/initial flowering (code 6:5) in the $2^{\text {nd }}$ year. There was a correlation between radionuclide interception and above ground biomass, as well with LAI, for both radionuclides in both years. The highest activity concentrations of both radionuclides were measured after deposition at the late growth stages and were found to be higher in the $2^{\text {nd }}$ year. There weathering half-lives were shorter at the earlier growth stages than at the later growth stages for both radionuclides. For the magnitude of deposition chosen in our experiment, it can be concluded that the above ground biomass is a good predictor and the LAI a more uncertain predictor of the interception of radiocaesium and radiostrontium by ley grass and clover.
\end{abstract}

Keywords: fodder crops, growth stages, radioactive deposition, weathering half-life, aggregated transfer factor

\section{Introduction}

The release of radionuclides into the atmosphere can result in their deposition on crops and soils. Several studies have reported that wet deposited radionuclides, e.g. radiocaesium and radiostrontium, can be intercepted and taken up directly the vegetation, for example through leaves (Bengtsson et al. 2013; Middleton, 1958; Middleton, 1959; Scotti and Carini, 2000). One of the most important pathway for the transfer of radionuclides, ${ }^{90} \mathrm{Sr}$ and ${ }^{137} \mathrm{Cs}$, to humans is through milk and meat consumption of animals that feed on contaminated fodder from ley and pasture (Fasenko et al., 2009; Gastberger et al., 2001; UNSCEAR, 2008). Milk obtained from contaminated agricultural fodder is a main source of the total collective dose to humans (Lepicard and Dubreuil, 2001; Madoz-Escande et al., 2004; Middleton, 1958). The levels of milk contamination by radionuclides depends on, among others, the foliar absorption by plant leaves and shoots, the root uptake of radionuclides from soil to crops, the consumption of contaminated soil by animals and the transfer of radionuclides from forage vegetation to milk (Gastberger et al., 2001).

The magnitude of radionuclide interception by crops depends on the concentration of radionuclides from the fallout, the intensity of the precipitation, time of year, plant morphology, i.e. the Leaf Area Index (LAI), the angle of leaves, above ground plant biomass, growth stage of the crop, the total amount of rain and wind (Eriksson et al., 1998; Hoffman et al., 1992; IAEA, 2010; Kinnersley et al., 1997; Pröhl, 2009). Other factors that can influence the level of radionuclide interception are the physical and chemical forms, i.e. the molecular mass and the valence (Bréchignac et al., 2000). Post-deposition retention of radionuclides is related to weathering processes such as wash-off of intercepted radionuclides by rain or irrigation, plant surface abrasion, re-suspension, age of plant tissues, litter fall, growth of new plant tissues, volatilisation, and evaporation (IAEA, 2009; Milbourne and Taylor, 1965). The proportion of the weathering loss of 
radionuclides depends on a number of factors, e.g. solubility, adsorption to the plant's surface and shedding of epicuticular wax (IAEA, 2009; Milbourne and Taylor, 1965). The cuticle layer of the epidermis of leaves is rather impermeable, but it contains cracks and defects through which radionuclides can enter the plant (Handley and Babcock, 1972; Hossain and Ryu, 2009; Tukey et al., 1961). The rate at which radionuclides can enter plants through their cuticle layer depends among others on temperature, light, $\mathrm{pH}$, the carrier of the radionuclides in the solution, the valence of the radionuclides and the type of crop (Marschner, 1986: Tukey et al., 1961). The length of the time period between interception of the radionuclides and the harvest of the crop also has an effect on the redistribution of the radionuclides within the crop (Coughtrey and Thorne, 1983; Kirchmann et al., 1967; Tukey et al., 1961). For grass crops, the concentration of radiocaesium in the biomass is likely to be highest in the first year after fallout. However, the transfer to the second cut can also be high, due to contributions from the previous seasons (Rosén et al., 1996; Rosén and Vinichuk, 2014).

The proportion of radioactivity directly intercepted by standing crop can be estimated as the interception fraction $(f)$, which is defined as the ratio between the activity concentration in the above ground plant biomass directly after deposition $\left(\mathrm{Bq} \mathrm{m}^{-2}\right)$ and the total amount of radionuclides deposited per unit area $\left(\mathrm{Bq} \mathrm{m}^{-}\right.$ $\left.{ }^{2}\right)$ (IAEA, 2010; Pröhl, 2009). Interception of radionuclides depends strongly on the biomass, and to account for this dependency the mass interception fraction $\left(f_{\mathrm{B}}, \mathrm{m}^{2} \mathrm{~kg}^{-1}\right)$ is introduced. The mass interception fraction is defined as the normalisation of the interception fraction of the above ground plant biomass ( $B, \mathrm{~kg} \mathrm{~m}^{-2}$, dry weight) (IAEA, 2010; Pröhl, 2009). The weathering effects of intercepted radionuclides can be estimated as the weathering halflife ( $T_{\mathrm{w}}$, days), which is defined as when $50 \%$ of the initial intercepted activity of radionuclides on the crops is obtained (IAEA, 2009). The transfer of radionuclides from the environment to crops in a given situation can be described by an aggregated transfer factor $\left(T_{\mathrm{ag}}, \mathrm{m}^{2} \mathrm{~kg}^{-1}\right)$; which is defined as the ratio between the post-deposited retained activity concentration of radionuclides in the crops $\left(\mathrm{Bq} \mathrm{kg}^{-1}\right)$ and the amount of radionuclides deposited per unit area $\left(\mathrm{Bq} \mathrm{m}{ }^{-2}\right.$ ) (Dahlgaard, 1994; Howard et al., 1996; IAEA, 2010) $T_{\mathrm{ag}}$-values calculated in connection to a previous deposition, or experimentally determined, can be used to evaluate the situation after a new radioactive deposition occasion occurs to facilitate decisions on countermeasures for prevention or at least reducing the potential transfer of radionuclides to animal fodder (Bengtsson et al., 2013; Howard et al., 1996;
Kostiainen et al., 2002; Rosén et al., 1996; Salbu, 2000).

The aims of this study were to measure the interception and activity concentrations of wet deposited ${ }^{134} \mathrm{Cs}$ and ${ }^{85} \mathrm{Sr}$ in ley at different growth stages; to examine the relationships between interception and activity concentrations and biomass in LAI and growth stage; to calculate the transfer of ${ }^{134} \mathrm{Cs}$ and ${ }^{85} \mathrm{Sr}$ in the above ground biomass through $T_{\mathrm{ag}^{-}}$ values. The hypothesis was ${ }^{134} \mathrm{Cs}$ and ${ }^{85} \mathrm{Sr}$ interception and activity are related to the type of radionuclide, the biomass, the LAI and the growth stage of the plant at the time of deposition.

\section{Materials and methods}

\subsection{Study area}

The study was conducted at the Ultuna meteorological and agricultural field station in Uppsala, Sweden $\left(59^{\circ} 48^{\prime} 45^{\prime \prime} \mathrm{N}\right.$ and $\left.17^{\circ} 38^{\prime} 45^{\prime \prime} \mathrm{E}\right)$. The soil's texture was: clay (60\% clay, $20 \%$ silt and $20 \%$ sand), $\mathrm{pH} 6.5$, plant available (ammonium lactate-acetate) phosphorus (P) $57 \mathrm{mg} \mathrm{kg}^{-1}$, potassium (K) $202 \mathrm{mg} \mathrm{kg}^{-1}$, and calcium (Ca) $3692 \mathrm{mg} \mathrm{kg}^{-1}$, total (HCl-soluble) P $638 \mathrm{mg} \mathrm{kg}^{-1}$, $\mathrm{K} 5720 \mathrm{mg} \mathrm{kg}^{-1}$ and $\mathrm{Ca} 6236 \mathrm{mg} \mathrm{kg}^{-1}$ (Bengtsson et al., 2012; Sandsborg and Wilert, 1975/1976).

The long-term (30 years, 1961-1990) annual mean air temperature was $5.6^{\circ} \mathrm{C}$ and the annual mean precipitation sum was $588 \mathrm{~mm}$ (SMHI, 2012). The growing season lasted from the $1^{\text {st }}$ May to the $30^{\text {th }}$ September, in both 2010 ( $1^{\text {st }}$ year $)$ and 2011 ( $2^{\text {nd }}$ year $)$. The mean annual air temperature of the growing season $\left(1^{\text {st }}\right.$ May to $30^{\text {th }}$ September) was $15^{\circ} \mathrm{C}$ in both the $1^{\text {st }}$ and $2^{\text {nd }}$ years, and the precipitation sums were $293 \mathrm{~mm}$ and $287 \mathrm{~mm}$ in the $1^{\text {st }}$ and $2^{\text {nd }}$ years, respectively (Bengtsson et al., 2013; Department of Crop Production Ecology, 2013). Air temperature at the deposition and sampling occasions varied between 10 and $21^{\circ} \mathrm{C}$, and there was very little or no precipitation in connection with deposition and sampling on any occasion during the study years. Wind speed at the deposition and sampling occasions was low and varied between 1.3 and $3.6 \mathrm{~m} \mathrm{~s}^{-1}$ in the $1^{\text {st }}$ year, and, 1.3 and $2.7 \mathrm{~m} \mathrm{~s}^{-1}$ in the $2^{\text {nd }}$ year (Department of Crop Production Ecology, 2013).

\subsection{Design of the experiment}

A trial with a randomised block design (each parcel was given a unique number and these numbers were randomised by using the computer program Excel 2010 v. 14.0.7128.5000 (C) Microsoft Corporation, (2010)), with 81 parcels (27 parcels (including 6 control parcels) $\times 3$ replicates) of $1 \times 1 \mathrm{~m}^{2}$ parcels was laid out in 2010 (Table 1). In order to cover seasonal variations, a new trial was laid out, with another 81 
parcels, in the adjacent field in 2011 (with already developed ley). The experimental ley was a mixture of clover and grass, which was composed of: $6 \%$ red clover (Trifólium praténse L.), 4\% white clover (Trifólium repens L.), $60 \%$ timothy (Phleum praténse L.), and $30 \%$ meadow fescue (Festúca praténsis L.). Ley was sown in the middle of May in 2010 on bare soil. Seedling rate was $25 \mathrm{~kg} \mathrm{ha}^{-1}$, and fertiliser rates were equivalent to $104 \mathrm{~kg} \mathrm{~N} \mathrm{ha}^{-1}$ and $19 \mathrm{~kg} \mathrm{P} \mathrm{ha}^{-1}$. As clay soil has a relatively high natural capacity for delivering $\mathrm{K}$ through weathering (202 $\mathrm{mg} \mathrm{kg} \mathrm{kg}^{-1}$ ) corresponds to a K-AL class of IV-V (of V), no Kfertiliser was needed according to Swedish standards (Yara International ASA, 2013).

The treatments in the experiment consisted of deposition of the ${ }^{134} \mathrm{Cs}$ (half-life of 2.07 years) and ${ }^{85} \mathrm{Sr}$ (half-life of 64.9 days) at six different growth stages, each treatment was carried out on three replicates. The growth stages were a combination of the growth stages of grass and clover (grass/clover). The growth stages, according to Halling (2005), were at the time of deposition in the $1^{\text {st }}$ year, rising, code 0:0; leaves, code $1: 1$ (leaves, leaves and petiole); tillering/growth of internode, code 2:2 (one node visible, most plants have visible internodes); beginning stem extension/initial budding, code 3:3 (part of spike and panicle visible:major stalk buddings visible); stem extension/initial flowering, code 4:5 (flag leaf visible:flowers visible on major stalk); and, spike and panicle/flowering, code 5:6 (spike and panicle fully visible:flowers visible on major stalk and side stalks) (Table 2).

The growth stages in the $2^{\text {nd }}$ year at the time of deposition were somewhat more advanced compared to the $1^{\text {st }}$ year; the growth stages at the time of deposition in the $2^{\text {nd }}$ year were spike and panicle/initial budding, code 4:3 (spike and panicle fully visible:separated buds in bud cluster); flowering/initial flowering, code 6:5 (full flowering:flowers visible on major stalk); flowering/flowering, code 6:6 (full flowering:flowers visible on major stalk and side stalks); postflowering/post-flowering, code 7:7; beginning stem extension/flowering, code 3:6 (part of spike and panicle visible:flowers visible on major stalk and side stalks); flowering/post-flowering, code 6:7 (full flowering:post-flowering) (Table 2).

A sampling of the above ground biomass was done directly after deposition and at the subsequent growth stages each time a new treatment started; thus, the number of samplings depended on how early in the season the treatment started, the first one had six samplings in total, the second one had five samplings in total etc. (Table 1). In addition three control plots were sampled every event.

The normal harvest of ley in the $1^{\text {st }}$ year corresponded to the growth stage code 5:6 $\left(2^{\text {nd }}\right.$ of
September). In the $2^{\text {nd }}$ year, the first normal harvest corresponded to the growth stage code $4: 3\left(26^{\text {th }}\right.$ of May); sub-sequent regrowth after code 7:7 rendered a second normal harvest at the growth stage with code $3: 6$ ( $24^{\text {th }}$ of August).

\subsection{Deposition of artificial radioactive rain}

In both years, the artificial rainwater was prepared from stock solutions and applied with a rainfall simulator, as described by Bengtsson et al. (2012). The stock solutions contained $5 \mathrm{MBq} \mathrm{L}^{-1}{ }^{134} \mathrm{Cs}$ and $15 \mathrm{MBq}$ $\mathrm{L}^{-1}{ }^{85} \mathrm{Sr}$ in the $1^{\text {st }}$ year, and $40 \mathrm{MBq} \mathrm{L}{ }^{-1}{ }^{134} \mathrm{Cs}$ and 37 $\mathrm{MBq} \mathrm{L}{ }^{-1}{ }^{85} \mathrm{Sr}$ in the $2^{\text {nd }}$ year. In the $1^{\text {st }}$ year, ${ }^{134} \mathrm{Cs}$ was in the form of caesium chloride $(\mathrm{CsCl})$ in a $0.1 \mathrm{M} \mathrm{HCl}$ solution (expanded uncertainty of $\pm 0.68 \%$ ) (GE Healthcare Limited, Amersham, UK), and ${ }^{85} \mathrm{Sr}$ was in the form of strontium chloride $\left(\mathrm{SrCl}_{2}\right)$ in a $0.5 \mathrm{M} \mathrm{HCl}$ solution (no expanded uncertainty provided) (Eckert \& Ziegler ${ }^{\mathrm{TM}}$, Santa Clarita, CA, USA). In the $2^{\text {nd }}$ year, ${ }^{134} \mathrm{Cs}$ was in the form of $\mathrm{CsCl}$ in a $0.1 \mathrm{M} \mathrm{HCl}$ solution (expanded uncertainty of $\pm 2.5 \%$ ) (Areva Cerca Lea, Pierrelatte Cedex, France). In the $1^{\text {st }}$ year, the amount of ${ }^{134} \mathrm{Cs}$ applied at different growth stages ranged from 24.5 to $30.9 \mathrm{kBq} \mathrm{m}^{-2}$ and ${ }^{85} \mathrm{Sr}$ ranged from 28.5 to 49.8 $\mathrm{kBq} \mathrm{m}^{-2}$ (details are given in Table 2). In the $2^{\text {nd }}$ year, the amounts of ${ }^{134} \mathrm{Cs}$ ranged from 40.5 to $41.0 \mathrm{kBq} \mathrm{m}^{-2}$ and ${ }^{85} \mathrm{Sr}$ ranged from 39.5 to $41.0 \mathrm{kBq} \mathrm{m}^{-2}$ (details are given in Table 2).

Due to stock solutions in the $1^{\text {st }}$ year being prepared with ultra-purified water in glass bottles, there was an adsorption of the radionuclides on the glass surface-Si$\mathrm{OH}$ group of the bottles through ion exchange adsorption (Lehto and Hou, 2011), so the amount of ${ }^{134} \mathrm{Cs}$ and ${ }^{85} \mathrm{Sr}$ that were applied differed between the two years. To minimise adsorption of the radionuclides in the $2^{\text {nd }}$ year, stable isotopes of $\mathrm{Cs}$ and $\mathrm{Sr}$ in the form as $\mathrm{CsCl}\left(150 \mathrm{~g} \mathrm{~L}^{-1}\right)$ in a $0.1 \mathrm{M} \mathrm{HCl}$ solution and $\mathrm{SrCl}_{2}$ $\left(150 \mathrm{~g} \mathrm{~L}^{-1}\right)$ in a $0.1 \mathrm{M} \mathrm{HCl}$ solution were added to the stock solutions, and they were stored in hydrophobic plastic bottles.

The amount of precipitation applied at each treatment

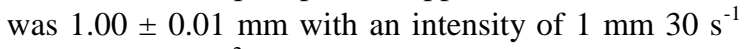
on a $60 \times 60 \mathrm{~cm}^{2}$ area in the middle of each parcel. A windshield was used to prevent wind disturbance during deposition in the early growth stages.

\subsection{Samplings and analysis}

The plants in three replicates were cut $5 \mathrm{~cm}$ above the soil surface (normal for harvest of a ley crop, and as well to avoid soil contamination) within a frame $(25 \times$ $25 \mathrm{~cm}^{2}$ square) in the middle of each parcel; two-three hours after deposition, additional replicates of each treatment were sampled with the following deposition occasions of all ongoing treatments (Table 1). In addition three replicates of control were sampled for each sampling occasion. The plant material was 
weighed fresh, and then air dried (at maximum of $40^{\circ} \mathrm{C}$ for about 14 days) before being re-weighed for determination of the dry weight (d.w.). Thereafter, the plant material was milled through a $2 \mathrm{~mm}$ sieve and placed in $35 \mathrm{~mL}$ or $60 \mathrm{~mL}$ plastic jars with a suitable geometry for measuring activity concentration.

Table 1. The schedule for the deposition and samplings, with three replicates for each combination of growth stage at deposition and sampling, where $Y=$ both deposition and sampling, $X=$ only sampling (time of deposition indicated by $Y$ in the same row).

\begin{tabular}{clllllll}
\hline Year & $\begin{array}{l}\text { Growth } \\
\text { stage at } \\
\text { deposition }\end{array}$ & & \multicolumn{3}{l}{ Growth stage at sampling } \\
\cline { 3 - 7 } & & $0: 0$ & $1: 1$ & $2: 2$ & $\mathbf{3 : 3}$ & $\mathbf{4 : 5}$ & $\mathbf{5 : 6}$ \\
\hline $1^{\text {st }}$ & $0: 0$ & $\mathrm{Y}$ & $\mathrm{X}$ & $\mathrm{X}$ & $\mathrm{X}$ & $\mathrm{X}$ & $\mathrm{X}$ \\
& $1: 1$ & & $\mathrm{Y}$ & $\mathrm{X}$ & $\mathrm{X}$ & $\mathrm{X}$ & $\mathrm{X}$ \\
& $2: 2$ & & & $\mathrm{Y}$ & $\mathrm{X}$ & $\mathrm{X}$ & $\mathrm{X}$ \\
& $3: 3$ & & & & $\mathrm{Y}$ & $\mathrm{X}$ & $\mathrm{X}$ \\
& $4: 5$ & & & & & $\mathrm{Y}$ & $\mathrm{X}$ \\
& $5: 6$ & & & & & & $\mathrm{Y}$ \\
\hline & & $\mathbf{4 : 3}$ & $\mathbf{6 : 5}$ & $6: 6$ & $7: 7$ & $\mathbf{3 : 6 ^ { * }}$ & $6: 7^{*}$ \\
\hline $2^{\text {nd }}$ & $4: 3$ & $\mathrm{Y}$ & $\mathrm{X}$ & $\mathrm{X}$ & $\mathrm{X}$ & $\mathrm{X}$ & $\mathrm{X}$ \\
& $6: 5$ & & $\mathrm{Y}$ & $\mathrm{X}$ & $\mathrm{X}$ & $\mathrm{X}$ & $\mathrm{X}$ \\
& $6: 6$ & & & $\mathrm{Y}$ & $\mathrm{X}$ & $\mathrm{X}$ & $\mathrm{X}$ \\
& $7: 7$ & & & & $\mathrm{Y}$ & $\mathrm{X}$ & $\mathrm{X}$ \\
& $3: 6^{*}$ & & & & & $\mathrm{Y}$ & $\mathrm{X}$ \\
& $6: 7^{*}$ & & & & & & $\mathrm{Y}$ \\
\hline
\end{tabular}

The activity concentration of the radionuclides were expressed as $\mathrm{Bq} \mathrm{kg}^{-1}$ d.w. and corrected for the decay. The samples obtained of the early growth stages with small amounts of biomass were corrected for the degree of filling of the $35 \mathrm{~mL}$ jars, and a correction factor for each detector was determined as described Bengtsson et al. (2012).

Measurements of ${ }^{134} \mathrm{Cs}$ and ${ }^{85} \mathrm{Sr}$ activity concentration were performed by using High Purity Germanium (HPGe)-detectors (GMX-13200, GMX33210, GMX-20200), and results were analysed and presented with the computer software Genie ${ }^{\mathrm{TM}} 2000$ (C Canberra, Meriden, Connecticut, USA (2009)). The measured activity concentration included uncertainties of the efficiency calibration of the HPGe-detectors, which were assumed to be one of the main sources of the total uncertainty (Bronson et al., 2008; Bengtsson et al., 2012). Uncertainty of the total amount of radionuclides deposited was estimated according to the method described in the Guide to the Expression of Uncertainty in Measurements (GUM) (Ellison et al., 2000; ISO, 1993), and reported as the combined standard uncertainty $u_{c}(y)$ for the total amount of radionuclides deposited. For the interception fraction $(f)$, the mass interception fraction $\left(f_{\mathrm{B}}\right)$ and the aggregated transfer factor $\left(T_{\mathrm{ag}}\right)$, the standard deviation was reported.

\subsection{Calculations of interception and transfer}

The interception fraction $(f)$ was calculated as the ratio between the activity in the above ground biomass directly after deposition $\left(A_{i}, \mathrm{~Bq} \mathrm{~m}^{-2}\right.$, d.w. $)$, and the total amount of activity deposited $\left(A_{t}, \mathrm{~Bq} \mathrm{~m}^{-2}\right.$, d.w.) (Eq. (1): (IAEA, 2010; Pröhl, 2009)).

$f=A_{i} / A_{t}$

The mass interception fraction $\left(f_{\mathrm{B}}, \mathrm{m}^{2} \mathrm{~kg}^{-1}\right)$ was calculated by normalising the interception fraction to the above ground plant biomass (B, $\mathrm{kg} \mathrm{m}^{-2} \mathrm{~d}$.w.) (Eq. 2): (IAEA, 2010; Pröhl, 2009)).

$$
f_{\mathrm{B}}=f / \mathrm{B} \quad\left[\mathrm{m}^{2} \mathrm{~kg}^{-1}\right]
$$

The aggregated transfer factors $\left(T_{\mathrm{ag}}, \mathrm{m}^{2} \mathrm{~kg}^{-1}\right)$ were calculated as the activity concentration of the specific radionuclide in the plants at harvest (sampling) $\left(A_{c}, \mathrm{~Bq}\right.$ $\mathrm{kg}^{-1}$, d.w.), divided by the amount of deposited activity $\left(A_{t}, \mathrm{~Bq} \mathrm{~m}^{-2}\right)(\mathrm{Eq}$ (3): (Dahlgaard, 1994; IAEA, 2010)).

$$
T_{\mathrm{ag}}=A_{c} / A_{t} \quad\left[\mathrm{~m}^{2} \mathrm{~kg}^{-1}\right]
$$

\subsection{Statistics}

Analyses of variance (ANOVA) were applied for ${ }^{134} \mathrm{Cs}$ and ${ }^{85} \mathrm{Sr}$ interception (only in the $2^{\text {nd }}$ year due to the different amounts in the $1^{\text {st }}$ year) to determine whether the interception was affected by the type of radionuclide. ANOVA were applied for the Tag-values of ${ }^{134} \mathrm{Cs}$ and ${ }^{85} \mathrm{Sr}$ to determine whether the Tag-values were affected by the growth stage, the year of deposition, or the type of radionuclide. To determine whether different types of radionuclides affected the total concentration of the two radionuclides in the ley at different sampling occasions, the ${ }^{85} \mathrm{Sr}$ interception from the linear regression was plotted against the ${ }^{134} \mathrm{Cs}$ interception, with one plot for each year. All statistical analyses were computed with the program $\mathrm{R}$ version 2.15.2 (@) The R Foundation for Statistical Computing, Vienna, Austria, 2012). 
Table 2. Shows the above ground plant biomass $\left(\mathrm{kg} \mathrm{m}^{-2}\right)$ and LAI $\left(\mathrm{m}^{2} \mathrm{~m}^{-2}\right)$, the means with standard deviation, the total amount $\left(A_{t}\right)$ of ${ }^{134} \mathrm{Cs}$ and ${ }^{85} \mathrm{Sr}\left(\mathrm{kBq} \mathrm{m} \mathrm{m}^{-2}\right)$ deposited with the total uncertainty $\left(u_{c}\right)$; the intercepted amount $\left(\mathrm{A}_{i}\right)$ of ${ }^{134} \mathrm{Cs}$ and ${ }^{85} \mathrm{Sr}\left(\mathrm{kBq} \mathrm{m}^{-2}\right)$ with standard deviation; the interception fraction $(f)$ of ${ }^{134} \mathrm{Cs}$ and ${ }^{85} \mathrm{Sr}$ with standard deviation; the mass interception fraction $\left(f_{B}\right)$ of ${ }^{134} \mathrm{Cs}$ and ${ }^{85} \mathrm{Sr}\left(\mathrm{m}^{2} \mathrm{~kg}^{-1} \times 10^{-3}\right)$ with standard deviation. The means are of three replicates $(n=3)$.

\begin{tabular}{|c|c|c|c|c|c|c|c|}
\hline \multirow{2}{*}{ Year } & \multirow{2}{*}{$\begin{array}{l}\text { Growth } \\
\text { stage at } \\
\text { deposition }\end{array}$} & \multirow{2}{*}{ Biomass } & \multirow{2}{*}{ LAI } & \multicolumn{2}{|c|}{ Total amount deposited $\left(A_{t}\right)$} & \multicolumn{2}{|c|}{ Intercepted amount $\left(A_{i}\right)$} \\
\hline & & & & ${ }^{134} \mathrm{Cs}$ & ${ }^{85} \mathrm{Sr}$ & ${ }^{134} \mathrm{Cs}$ & ${ }^{85} \mathrm{Sr}$ \\
\hline \multirow[t]{6}{*}{$1^{\text {st }}$} & $0: 0$ & $0.002 \pm 0.001$ & - & $24.5 \pm 0.2$ & $41.9 \pm 1.3$ & $0.0 \pm 0.0$ & $0.0 \pm 0.0$ \\
\hline & $1: 1$ & $0.008 \pm 0.03$ & $0.6 \pm 0.2$ & $26.8 \pm 0.3$ & $28.5 \pm 0.9$ & $0.2 \pm 0.2$ & $0.27 \pm 0.2$ \\
\hline & $2: 2$ & $0.04 \pm 0.02$ & $1.5 \pm 0.4$ & $25.9 \pm 1.9$ & $41.2 \pm 1.2$ & $0.6 \pm 0.3$ & $1.42 \pm 0.5$ \\
\hline & $3: 3$ & $0.09 \pm 0.05$ & $2.3 \pm 0.7$ & $26.8 \pm 1.7$ & $38.5 \pm 2.7$ & $1.0 \pm 0.7$ & $2.13 \pm 1.4$ \\
\hline & $4: 5$ & $0.17 \pm 0.03$ & $4.4 \pm 0.4$ & $30.9 \pm 2.0$ & $49.8 \pm 1.8$ & $2.7 \pm 1.1$ & $4.85 \pm 1.7$ \\
\hline & $5: 6$ & $0.35 \pm 0.15$ & $5.7 \pm 0.6$ & $26.6 \pm 1.7$ & $49.4 \pm 3.4$ & $7.3 \pm 1.8$ & $15.8 \pm 4.5$ \\
\hline \multirow[t]{6}{*}{$2^{\text {nd }}$} & $4: 3$ & $0.06 \pm 0.06$ & $1.6 \pm 0.8$ & $40.6 \pm 0.34$ & $39.5 \pm 0.9$ & $1.0 \pm 1.0$ & $1.0 \pm 1.1$ \\
\hline & $6: 5$ & $0.93 \pm 0.56$ & $1.8 \pm 0.6$ & $40.5 \pm 0.34$ & $40.6 \pm 0.9$ & $13.9 \pm 15.3$ & $15.0 \pm 15.7$ \\
\hline & $6: 6$ & $0.67 \pm 0.14$ & $1.1 \pm 1.8$ & $41.0 \pm 0.4$ & $40.6 \pm 0.9$ & $12.6 \pm 1.9$ & $13.3 \pm 1.4$ \\
\hline & $7: 7$ & $0.33 \pm 0.09$ & $0.9 \pm 0.9$ & $41.0 \pm 0.4$ & $41.0 \pm 0.9$ & $6.5 \pm 2.8$ & $6.9 \pm 3.0$ \\
\hline & $3: 6^{*}$ & $0.20 \pm 0.09$ & $0.5 \pm 0.5$ & $40.6 \pm 0.4$ & $40.6 \pm 0.9$ & $8.5 \pm 2.9$ & $8.6 \pm 2.9$ \\
\hline & $6: 7 *$ & $0.17 \pm 0.08$ & $2.2 \pm 2.2$ & $41.0 \pm 0.4$ & $40.4 \pm 0.9$ & $3.9 \pm 2.0$ & $5.1 \pm 2.5$ \\
\hline
\end{tabular}

\section{Results and Discussion}

\subsection{Interception of ${ }^{134} \mathrm{Cs}$ and ${ }^{85} \mathrm{Sr}$}

For both radionuclides, the fraction intercepted by ley increased with the increase in above ground biomass and LAI in both years (Fig. 1). The relationship between the intercepted fraction $(f)$ of radionuclides and above ground biomass (d.w.) was significant in both years (Figs. 1A and B). A similar relationship between $f$ and above ground biomass was found by Vandecasteele et al. (2001) for wheat, although their values for this crop were higher $\left(0.84\right.$ for ${ }^{134} \mathrm{Cs}$ and 0.88 for $\left.{ }^{85} \mathrm{Sr}\right)$. The relationship between the intercepted fraction of each radionuclide and the LAI in both years was also significant (Figs. 1C and D), although a weaker relationship was found for the $2^{\text {nd }}$ year.

The intercepted fraction $(f)$ and mass intercepted fraction $\left(f_{\mathrm{B}}\right)$ of both radionuclides were highest after deposition just before the last normal harvest (growth stage 5:6) in the $1^{\text {st }}$ year (Fig. 2 and Table 2) and the control plots did not intercepted any activity of the radionuclides as they did not receive any radioactive deposition. In the $2^{\text {nd }}$ year, $f$ was low at the first deposition occasion, and then increased drastically at the $2^{\text {nd }}$ deposition occasion, followed by a gradual decrease at later depositions occasions. For the $f_{\mathrm{B}}$, the lowest values for both radionuclides were at the first deposition occasion, and then the values increased at the $2^{\text {nd }}$ deposition occasion, followed by more or less the same magnitude at later deposition occasions, followed by a drastic increase at the deposition at growth stage $3: 6$. Variations in $f$ can be explained by the variation from the biomass (from $0.35 \pm 0.15 \mathrm{~kg} \mathrm{~m}^{-}$ ${ }^{2}$ at last sampling occasion (growth stage 5:6) in the $1^{\text {st }}$ year, to $0.06 \pm 0.06 \mathrm{~kg} \mathrm{~m}^{-2}$ at the first sampling occasion (growth stage $4: 3$ ) in the $2^{\text {nd }}$ year. In the $2^{\text {nd }}$ year, the ley had a quick regrowth in the beginning of the growing season, which decreased its (living) biomass later on as a fold of the ageing and dry spells (Table 2), and the harvest further reduced the biomass. Intercepted $f$ - and $f_{\mathrm{B}}$-values were higher for ${ }^{85} \mathrm{Sr}$ than for ${ }^{134} \mathrm{Cs}$ at several growth stages. Higher interception values for radiostrontium than for radiocaesium were also observed for spring wheat by Bengtsson et al. (2012) and Vandecasteele et al. (2001). Divalent ions, like ${ }^{85} \mathrm{Sr}$, are expected to be more efficiently adsorbed on plant surfaces than monovalent ions, like ${ }^{134} \mathrm{Cs}$ (Aarkrog, 1969; Bréchignac et al., 2000; Vandecasteele et al., 2001). 


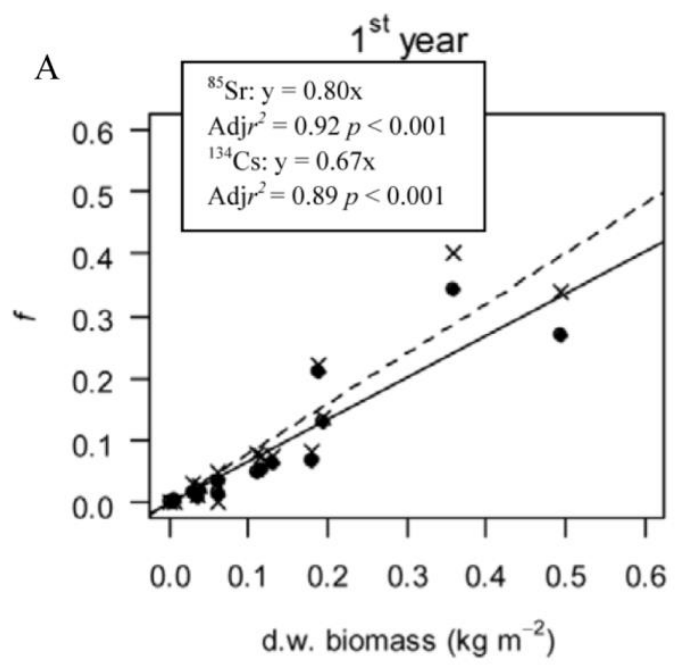

$\mathrm{C}$

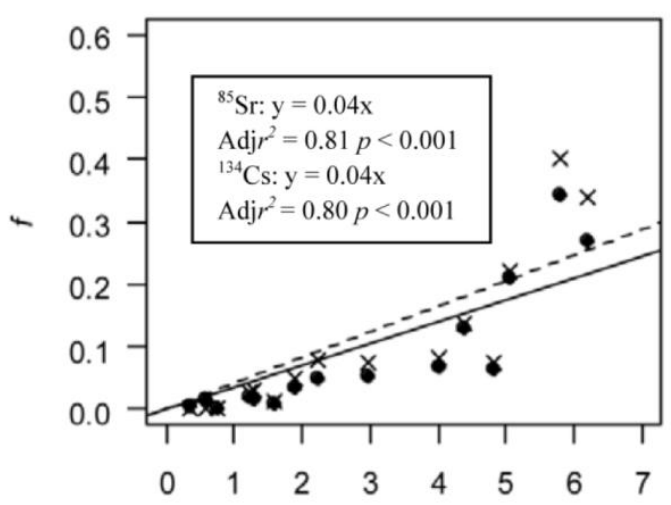

LAI
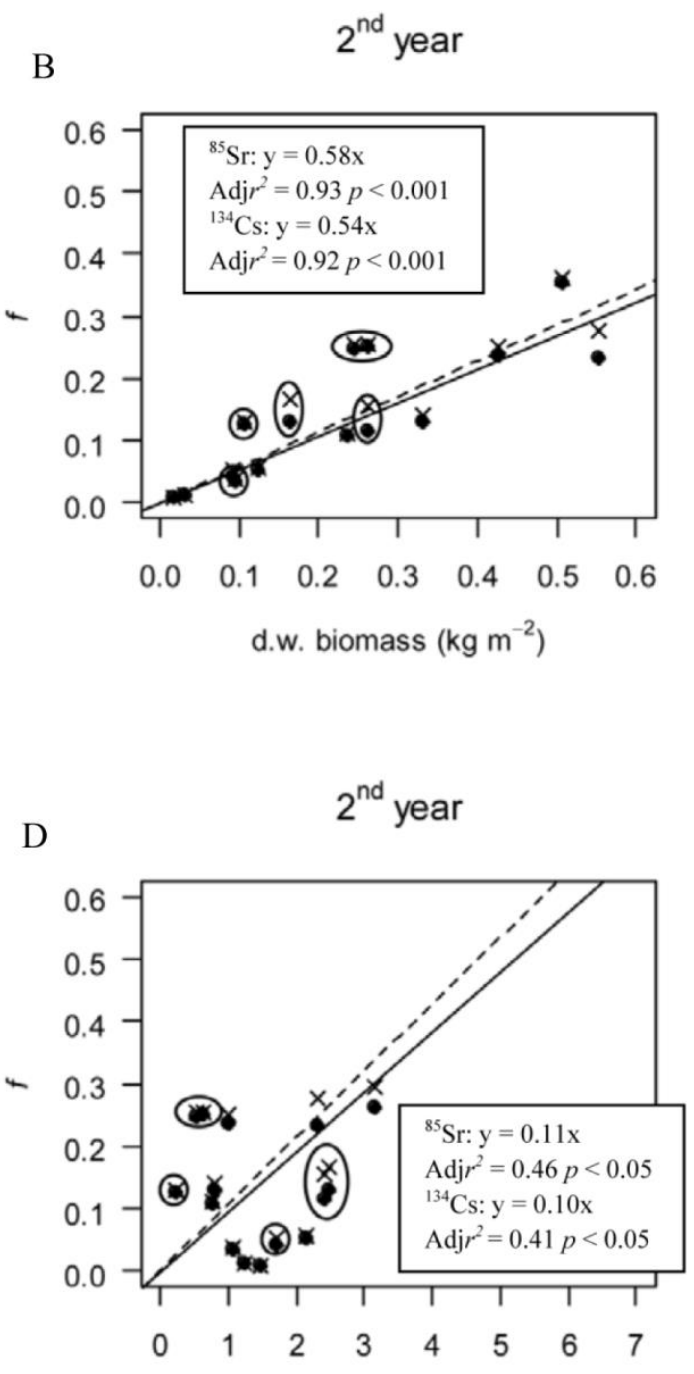

LAI

Figure 1A-D. The relationship between interception fraction $(f)$ for ${ }^{134} \mathrm{Cs}(\bullet,-)$ and ${ }^{85} \mathrm{Sr}(\times,--)$ deposited on a ley and above ground plant biomass d.w. (1A and 1B) and LAI (1C and 1D). The encircled points in $2^{\text {nd }}$ year are values measured in normal sampling times for the second harvest of a regrowth.

This effect might be more pronounced when sampling occurs shortly after deposition; as in this short time-lag, negligible amounts of radionuclides were washed-off. However, the fraction of radionuclides intercepted by ley was not only related to the valence of radionuclides, but it was also related to the water storage capacity and accumulation of the radionuclides on crop surfaces (Kinnersley et al., 1997). Our results might have been influenced by the high rain intensity during the 30 second application (1 $\mathrm{mm} 30 \mathrm{~s}^{-1}$ ). The bigger drops connected to higher rain intensities tend to splash off the plants to a higher degree than the smaller ones at lower rain intensities (Keim et al., 2006; Wang et al., 2005). Moreover, the application of more than $1 \mathrm{~mm}$ of rain could have resulted in a lower interception of radionuclides, because as the maximum water storage capacity on the crops surfaces is reached more quickly, further water will run off from the crops surfaces (Kinnersley et al., 1997).

As an average, ley intercepted (mean values of three replicates) up to $27 \%\left(7 \mathrm{kBq} \mathrm{m}^{-2}\right)$ of the deposited amount of ${ }^{134} \mathrm{Cs}$ in the $1^{\text {st }}$ year, and up to $34 \%(14 \mathrm{kBq}$ $\mathrm{m}^{-2}$ ) (mean values of three replicates) in the $2^{\text {nd }}$ year. This is quite similar to the data reported by Eriksson $e t$ al. (1998), where up to $39 \%$ of ${ }^{134} \mathrm{Cs}$ was intercepted by ley. The percentage of intercepted ${ }^{85} \mathrm{Sr}$ (mean values of three replicates) were up to $32 \%\left(16 \mathrm{kBq} \mathrm{m}^{-2}\right)$ in the $1^{\text {st }}$ year and up to $37 \%\left(15 \mathrm{kBq} \mathrm{m}^{-2}\right)$ (mean values of three replicates) in the $2^{\text {nd }}$ year; which is in agreement with data obtained by Milbourne and Taylor (1965), where up to $30 \%$ of the deposited amount of ${ }^{85} \mathrm{Sr}$ was 
intercepted on a permanent pasture. However, it is possible that interception of radionuclides could have been underestimated rather than overestimated, since some of the amount of radioactivity was likely to be intercepted by the lower parts of the plant.

In a comparable experiment, Chadwick and Chamberlain (1970), found the interception of grass to be in a similar range $\left({ }^{85} \mathrm{Sr}: 0.20-0.82\right)$, as in the presented study $\left({ }^{134} \mathrm{Cs}\right.$ : $>0.01-0.76 ;{ }^{85} \mathrm{Sr}$ : >0.01-0.80). Similarly, Eriksson et al. (1998) and Madoz-Escande et al. (2004) found in a comparable experiment on leys and common beans that the highest $f$ for ${ }^{134} \mathrm{Cs}(0.71$, ours: 0.76$)$ and for ${ }^{85} \mathrm{Sr}$ (1.11, ours: 0.80 ) is $24 \mathrm{~h}$ after deposition, with $f$ increasing with the biomass.
Based on ANOVA analyses, the $f$-values for the $2^{\text {nd }}$ year were more or less the same for ${ }^{85} \mathrm{Sr}$ and ${ }^{134} \mathrm{Cs}(p=$ 0.80 when testing the hypothesis that they were different) when compared over different deposition occasions. ANOVA analyses were done only for the $2^{\text {nd }}$ year, as higher amount of ${ }^{85} \mathrm{Sr}$ was deposited in the $1^{\text {st }}$ year due to experimental error (Table 2).

An intercepted fraction that has been determined in one situation needs to be used with caution for prediction of crop contamination in a new situation, since its magnitude can vary with plant type, type of radionuclide, magnitude and intensity of rainfall, the concentration of radionuclides in the rain, weather conditions, and biomass (Bengtsson et al., 2012; Hoffman et al., 1992; Kinnersley et al., 1997).
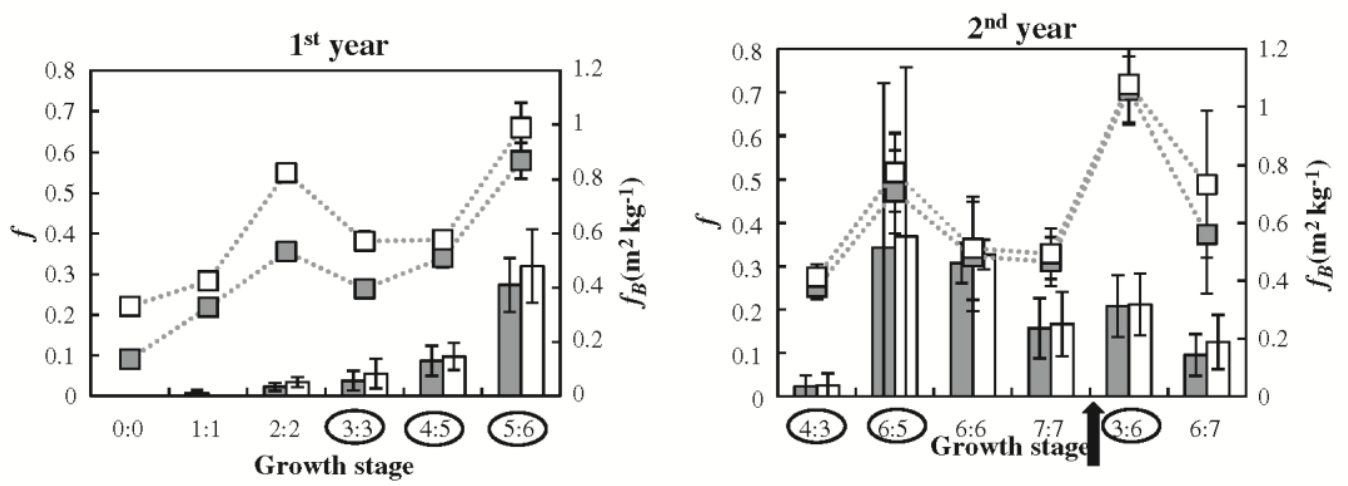

Figure 2. The interception fraction $(f)$ and the mass interception fraction $\left(f_{\mathrm{B}}\right)$ after deposition of ${ }^{134} \mathrm{Cs}(\mathbf{\square})$ and ${ }^{85} \mathrm{Sr}(\square)$ at different growth stages in a ley ( $n=3$ at all growth stages). The error bars indicate standard deviation. The arrow in the $2^{\text {nd }}$ year diagram indicates when regrowth started after the first harvest.

The relationship between radionuclide intercepted fraction and LAI in both years was also significant (Figure $1,{ }^{134} \mathrm{Cs}$ interception $/{ }^{85} \mathrm{Sr}$ interception vs. LAI, and by year), showing that the interception increases with increasing LAI.

An intercepted fraction determined in one situation need to be used with caution for prediction of crop contamination in a new situation since its magnitude varies with plant type, type of radionuclide, level of rainfall and the concentrations of radionuclides in the rain (Hoffman et al., 1992; Kinnersley et al., 1997).

The fraction of radionuclides intercepted by ley is not directly related to the intensity of rainfall but rather to the water storage capacity and accumulation of the radionuclides on the crop surfaces (Kinnersley et al., 1997). Still, our results might have been influenced by the high rain intensity during the 30 second application

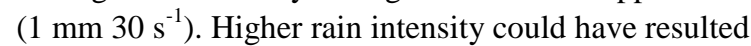
in lower values of interception, as bigger droplets tend to splash off the plants to a higher degree than at lower rain intensities with smaller drops (Keim et al., 2006; Wang et al., 2005). The risks that water interception capacity was exceeded at prevailing LAI was low as only $1 \mathrm{~mm}$ was added (Kinnersley et al., 1997).

\subsection{Activity concentration of ${ }^{134} \mathrm{Cs}$ and ${ }^{85} \mathrm{Sr}$}

The weathering half-life $\left(T_{\mathrm{w}}\right)$ of the retained intercepted radionuclides was in general much shorter at the earlier growth stages when the ley had a quick growth of its biomass ( 10 days for ${ }^{134} \mathrm{Cs}$ and 8 days for ${ }^{85} \mathrm{Sr}$ ) (Table 3). At later growth stages the weathering half-life was in general longer for both radionuclides (24 days for ${ }^{134} \mathrm{Cs}$ and 22 days for ${ }^{85} \mathrm{Sr}$ ).

Table 3. Shows the weathering half-life $\left(T_{\mathrm{w}}\right)$ of ${ }^{134} \mathrm{Cs}$ and ${ }^{85} \mathrm{Sr}$ (days), including growth dilution.

\begin{tabular}{llll}
\hline Year & $\begin{array}{l}\text { Growth stage } \\
\text { at deposition }\end{array}$ & \multicolumn{2}{l}{ Weathering half-life $\left(T_{\mathrm{w}}\right)$} \\
\cline { 3 - 4 } & & ${ }^{134} \mathrm{Cs}$ & ${ }^{85} \mathrm{Sr}$ \\
\hline $1^{\text {st }}$ & $0: 0$ & $8^{\dagger}$ & $8(8-8.5)$ \\
& $1: 1$ & $8.5(8-9)$ & $8(7.5-9)$ \\
& $2: 2$ & $6(5.5-6)$ & $5(5-5.5)$ \\
$2^{\text {nd }}$ & $3: 3$ & $15.5(15.5-16)$ & $15(15-15.5)$ \\
& $4: 3$ & $10(7-13.5)$ & $7.5(6.5-9)$ \\
& $6: 5$ & $14(13.5-14.5)$ & $7(6.5-7)$ \\
& $6: 6$ & $26(15.5-44)$ & $24(14.5-41)$ \\
& $7: 7$ & $21(13-31.5)$ & $20(13-30.5)$ \\
\hline
\end{tabular}

The means and ranges are of three replicates $(n=3)$, except where ${ }^{\dagger} n=1$. The two last deposition occasions were not included due to lack of data. 
The activity concentration of both radionuclides was in general lower in the $1^{\text {st }}$ year than in the $2^{\text {nd }}$ year, and this could be explained by the fact that the ley was established in the $1^{\text {st }}$ year on bare soil and/or also by yearly variations in the season (Fig. 3). It should be borne in mind that in the $1^{\text {st }}$ year, normal harvest (growth stage 5:6) was made very late in the season; i.e. in the beginning of September, since the ley grass was sown in the spring and needed some time for establish itself. In the $2^{\text {nd }}$ year, the $1^{\text {st }}$ normal harvest (growth stage 4:3) occurred in the beginning of June. The controls did not have any activity concentrations of the radionuclides, as they did not receive any radioactive deposition.

Generally, the closer the sampling after deposition and the more developed the crop, the higher the activity concentration of both radionuclides (Fig. 3). This is in agreement with data obtained by Mårtensson (2012) for ley. The dynamics of the activity concentrations showed that quite some radioactivity was lost between sampling occasions, for instance between sampling at growth stage 3:3 and 4:5 for the $2^{\text {nd }}, 3^{\text {rd }}$ and $4^{\text {th }}$ deposition in the $1^{\text {st }}$ year, and sampling at growth stage $6: 5$ in the $2^{\text {nd }}$ year; the explanation for this could be related to precipitation.
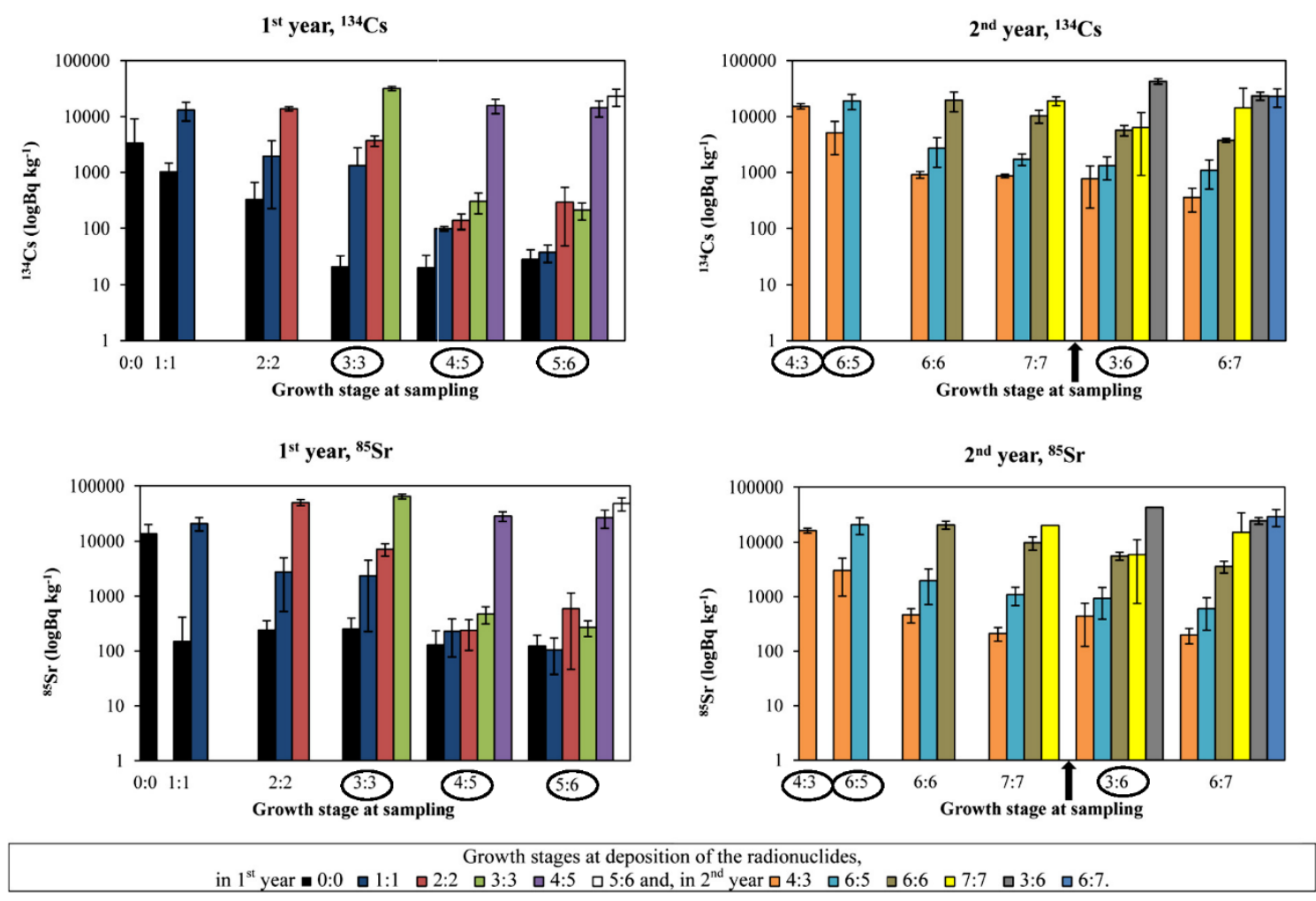

Figure 3. Logged activity concentrations of ${ }^{134} \mathrm{Cs}$ and ${ }^{85} \mathrm{Sr}$ at different sampling occasions after deposition at different growth stages ( $n=3$ at all growth stages except at deposition/sampling in the $2^{\text {nd }}$ year at deposition/sampling $(6: 5 / 6: 6)$ where $\left.n=2\right)$. Error bars indicate standard deviation. Encircled are the growth stages at which harvest normally occurs. The arrow indicates when regrowth started after the first harvest in the $2^{\text {nd }}$ year.

In general, in the $1^{\text {st }}$ year the activity concentrations of radiostrontium in the ley were found to be higher than that of radiocaesium; however, this could be explained by the higher amount of ${ }^{85} \mathrm{Sr}$ deposited due to experimental error (Table 2). In the $2^{\text {nd }}$ year, the activity concentrations of radiocaesium in the ley were found to be higher than that of radiostrontium, and this was in agreement with Eriksson et al. (1998), who found that the activity concentration of radiocaesium in ley was generally higher than that of radiostrontium. All comparisons between radionuclide accumulation in the ley were significant $\left(\operatorname{Adj} R^{2}=0.99, p<0.05\right.$ for both years and dy/dx was $1.161^{\text {st }}$ year and $1.072^{\text {nd }}$ year, with intercept of 0.00 in both years) and plots of the data can be found in the Appendix in Supplementary Data 2. This indicates that both radionuclides were similarly absorbed by the plant tissue. The smaller amount of radionuclides absorbed by the ley at deposition in early growth stages could be due to more wash-off after fall-off in early growth stages, and the dilution effects because more rapid growth of the plant in the early stages took place (Colle et al., 2009; Eriksson et al., 1998). 
The $T_{\mathrm{ag}}$-values (Table 4) varied between treatments in a similar way to the activity concentrations of the two radionuclides, since a more or less equal amount of radioactivity was applied per square meter in the $2^{\text {nd }}$ year in all treatments and on all occasions (i.e. the denominator in Eq. (2) is constant).

Table 4. Shows aggregated transfer factors $\left(T_{a g}\right)\left(\mathrm{m}^{2} \mathrm{~kg}^{-1} \times 10^{-3}\right)$ of ${ }^{134} \mathrm{Cs}$ and ${ }^{85} \mathrm{Sr}$ for the different combinations of wetdepositions and samplings of ley at different growth stage, with the mean and standard deviation of three replicates $(n=3)$.

\begin{tabular}{|c|c|c|c|c|c|c|}
\hline \multirow[t]{3}{*}{ Year } & \multirow{3}{*}{$\begin{array}{l}\text { Growth stage at } \\
\text { deposition }\end{array}$} & \multicolumn{5}{|l|}{${ }^{134} \mathrm{Cs}$} \\
\hline & & \multicolumn{5}{|c|}{ Growth stage at sampling } \\
\hline & & $1: 1$ & $2: 2$ & $3: 3$ & $4: 5$ & $5: 6$ \\
\hline \multirow[t]{6}{*}{$1^{\text {st }}$} & $0: 0$ & $28 \pm 27$ & $6.2 \pm 1.8$ & $0.29 \pm 0.5$ & $0.55 \pm 0.61$ & $1.2 \pm 0.58$ \\
\hline & $1: 1$ & & $73 \pm 65$ & $50 \pm 53$ & $2.5 \pm 1.8$ & $1.4 \pm 0.49$ \\
\hline & $2: 2$ & & & $143 \pm 31$ & $5.3 \pm 1.6$ & $11 \pm 9.4$ \\
\hline & $3: 3$ & & & & $11 \pm 4.6$ & $7.9 \pm 2.7$ \\
\hline & $4: 5$ & & & & & $468 \pm 177$ \\
\hline & & $6: 5$ & $6: 6$ & $7: 7$ & $3: 6^{*}$ & $6: 7^{*}$ \\
\hline \multirow[t]{8}{*}{$2^{\text {nd }}$} & $4: 3$ & $126 \pm 75$ & $23 \pm 3.1$ & $21 \pm 2.9$ & $19 \pm 13$ & $8.8 \pm 4.0$ \\
\hline & $6: 5$ & & $67 \pm 37$ & $43 \pm 8.4$ & $32 \pm 15$ & $18 \pm 19$ \\
\hline & $6: 6$ & & & $252 \pm 62$ & $140 \pm 29$ & $92 \pm 7.1$ \\
\hline & $7: 7$ & & & & $155 \pm 134$ & $352 \pm 430$ \\
\hline & $3: 6^{*}$ & & & & & $581 \pm 97$ \\
\hline & & ${ }^{85} \mathrm{Sr}$ & & & & \\
\hline & & Growth s & at sampling & & & \\
\hline & & 1:1 & $2: 2$ & $3: 3$ & $4: 5$ & $5: 6$ \\
\hline \multirow[t]{6}{*}{$1^{\mathrm{st}}$} & $0: 0$ & $3.6 \pm 6.2$ & $3.9 \pm 3.9$ & $2.0 \pm 3.5$ & $2.1 \pm 2.5$ & $3.0 \pm 1.7$ \\
\hline & $1: 1$ & & $97 \pm 79$ & $83 \pm 75$ & $4.1 \pm 5.5$ & $3.7 \pm 2.4$ \\
\hline & $2: 2$ & & & $175 \pm 45$ & $5.8 \pm 3.3$ & $14 \pm 13$ \\
\hline & $3: 3$ & & & & $12 \pm 4.2$ & $7.0 \pm 2.3$ \\
\hline & $4: 5$ & & & & & $544 \pm 198$ \\
\hline & & $6: 5$ & $6: 6$ & $7: 7$ & $3: 6^{*}$ & $6: 7^{*}$ \\
\hline \multirow[t]{5}{*}{$2^{\text {nd }}$} & $4: 3$ & $77 \pm 51$ & $12 \pm 3.5$ & $5.4 \pm 1.5$ & $11 \pm 8$ & $5.0 \pm 1.6$ \\
\hline & $6: 5$ & & $48 \pm 31$ & $27 \pm 9.9$ & $23 \pm 13$ & $10 \pm 11$ \\
\hline & $6: 6$ & & & $241 \pm 67$ & $138 \pm 23$ & $88 \pm 22$ \\
\hline & $7: 7$ & & & & $150 \pm 127$ & $371 \pm 473$ \\
\hline & $3: 6^{*}$ & & & & & $609 \pm 87$ \\
\hline
\end{tabular}

* indicates regrowth with a second harvest in the $2^{\text {nd }}$ year (2011) after growth stage 7:7. The growth stages relevant for a normal harvest of ley are bolded.

Since the aggregated transfer factors have a tendency to get higher the closer the deposition occasions were to the sampling occasion, the interception alone does not explain the final activity concentration in the crop. In the $2^{\text {nd }}$ year, the $T_{\mathrm{ag}}$-values increased even when the interception decreased, and this can be explained by the fact that a lower biomass will contribute to higher $T_{\text {ag }}$-values, even with lower interception (see Table 2 for values on the biomass). Other contributing factors could be the dilution of radionuclide concentration due to the growth of the biomass (Coughtrey and Thorne, 1983), the leaves falling-off during the time between the deposition and sampling occasion (Colle et al., 2009; Eriksson et al., 1998) and the decay rate of the radionuclides (Choi et al., 2002).
According to the ANOVA test, $T_{\mathrm{ag}}$-values for both radionuclides were dependent on the growth stage of the crops $(p<0.05)$, and on the year of the experiment $(p<0.001)$. However, the $T_{\mathrm{ag}}$-values did not differ significantly between the radionuclides $(p=0.93)$, as they ranged between $<0.00$ and 0.849 for ${ }^{134} \mathrm{Cs}$ and $<0.00$ to 0.917 for ${ }^{85} \mathrm{Sr}$. A similar range in $T_{\mathrm{ag}}$-values $\left({ }^{134} \mathrm{Cs}\right.$ : $0.005-1.594 ;{ }^{85} \mathrm{Sr}$ : 0.000-1.140) was reported by Eriksson et al. (1998). Even if the transfer factors were in agreement with those in other studies, the variation of the $T_{\mathrm{ag}}$-values stresses the uncertainty of Tag-values, and the need for more experiments and analyses to be done with emphasis placed on weather. For this reason, preliminary assessment of activity concentration in fodder crops needs to be done by continuous sampling and monitoring in the case of a radioactive deposition. 


\section{Conclusions}

The interception of radionuclides was highest when deposition occurred at the well-developed ley during the later or latest growth stages before harvest. For the magnitude of deposition chosen in our experiment, it can be concluded that the above ground biomass is a good predictor and the LAI a more uncertain predictor of the interception of radiocaesium and radiostrontium by ley grass and clover. The $T_{\mathrm{w}}$-values of retained intercepted radionuclides were much higher when deposition occurred at the well-developed ley during the later or latest growth stages before harvest.

The variation in magnitude of aggregated transfer factor values between different deposition occasions fits well with those found in other studies. However, it should be noted that there are few investigations where transfer factors are related to deposition rates and to the deposition of radionuclides in growing ley. The variation in Tag-values, which could then be used as trustworthy prediction measures of radionuclides in crops after possible future fallout

\section{Acknowledgments}

This project was financed by the Swedish Radiation Safety Authority and by the Swedish Board of Agriculture. We would like to thank the staff of the Radioecology section, especially to MSc Kristin Thored, MSc Yosief Tesfatsion, MSc Anna-Lisa Mårtensson, and Mr Giovanni Nigrinis for their help with the field work. We thank the three anonymous referees for constructive comments. We would also like to thank our colleagues in the Biogeochemistry and Environmental Assessment research group, especially MSc Martin Rappe George, for his essential and supportive discussions about this paper.

\section{References}

Aarkrog A. On direct contamination of rye, barley, wheat and oats with ${ }^{85} \mathrm{Sr},{ }^{134} \mathrm{Cs},{ }^{54} \mathrm{Mn}$ and ${ }^{141} \mathrm{Ce}$. Radiat Bot 1969; 9: 357-366.

Bengtsson SB, Eriksson J, Gärdenäs AI, Rosén K. Influence of development stage of spring oilseed rape and spring wheat on interception of wet-deposited radiocaesium and radiostrontium. Atmospheric Environment 2012; 60: 227233.

Bengtsson SB, Eriksson J, Gärdenäs AI, Vinichuk M, Rosén K. Accumulation of wet-deposited radiocaesium and radiostrontium by spring oilseed rape (Brássica napus L.) and spring wheat (Tríticum aestívum L.). Environmental Pollution 2013; 182: 335-342.

Bréchignac F, Vallejo R, Vandecasteele C, Shaw G, Forsberg $\mathrm{S}$, Madoz-Escande C. Improving the short and long term prediction ability of radiocontaminant behavior in agro- ecosystems, Rapport Scientifique et Technique IPSN RST 20002000.

Bronson F, Atrashkevich V, Geurkov G, Young B. Probabilistic uncertainty estimator for gammaspectroscopy measurements. Journal of Radioanalytical and Nuclear Chemistry 2008; 276: 589-594.

Chadwick RC, Chamberlain AC. Field loss of radionuclides from grass. Atmosperic Environment (1967) 1970; 4: 5156.

Choi YH, Lim KM, Yu D, Park HG, Choi YG, Lee CM. Transfer pathways of Mn-54, Co-57, Sr-85, Ru-103 and Cs-134 in rice and radish plants directly contaminated at different growth stages. Annals of Nuclear Energy 2002; 29: 429-446.

Colle C, Madoz-Escande C, Leclerc E. Foliar transfer into the biosphere: review of translocation factors to cereal grains. Journal of Environmental Radioactivity 2009; 100: 683689.

Coughtrey PJ, Thorne MC. Radionuclide Distribution and Transport in Terrestrial and Aquatic Ecosystems A Critical Review of Data. Rotterdam: A.A.Balkema, 1983.

Dahlgaard H. Nordic radioecology: the transfer of radionuclides through nordic ecosystems to man. Amsterdam: Elsevier; 1994.

Department of Crop Production Ecology, Swedish University of Agricultural Science. SLU Ultuna climate. 2013, Uppsala, Sweden, 2013.

Ellison SLR, Rosslein M, Williams A. Quantifying uncertainty in analytical measurment. 2nd. EURACHEM/CITAC, 2000, pp. 120.

Eriksson Å, Rosén K, Haak E. Retention of Simulated Fallout Nuclides in Agricultural Crops, I. Experiments on Leys. SLU-REK-80. Institutionen för radioekologi, SLU, 1998, pp. 32.

Fesenko S, Isamov N, Howard BJ, Beresford NA, Barnett CL, Sanzharova N, et al. Review of Russian language studies on radionuclide behaviour in agricultural animals: 3. Transfer to muscle. Journal of Environmental Radioactivity 2009; 100: 215-231.

Gastberger M, Steinhäusler F, Gerzabek MH, Hubmer A. Fallout strontium and caesium transfer from vegetation to cow milk at two lowland and two Alpine pastures. Journal of Environment Radioactivity 2001; 54: 267-273.

Halling MA. Vallväxter till slåtter och bete samt grönfoderväxter sortvall för södra och mellersta Sverige 2005/2006. Sveriges lantbruksuniversitet, Ekologi och växtproduktionslära, Uppsala, 2005.

Handley R, Babcock KL. Translocation of ${ }^{85} \mathrm{Sr},{ }^{137} \mathrm{Cs}$, and ${ }^{106} \mathrm{Ru}$ in crop plants. Radiation Botany 1972; 12: 113-119.

Hoffman FO, Thiessen KM, Frank ML, Blaylock BG. Quantification of the interception and initial retention of radioactive contaminants deposited on pasture grass by simulated rain. Atmospheric Environment Part a-General Topics 1992; 26: 3313-3321.

Hossain MB, Ryu KS. Effect of foliar applied phosphatic fertilizer on absorption pathways, yield and quality of sweet persimmon. Scientia Horticulturae 2009; 122: 626632.

Howard BJ, Johansson K, Linsley GS, Hove K, Pröhl G, Horyna J. Transfer of radionuclides by terrestrial food products from semi-natural ecosystems to humans, Modelling of radionuclide interception and loss processes 
in vegetation and of transfer in semi-natural ecosystems. In: International Atomic Energy Agency, editor. Technical reports series No. 857, Vienna, 1996.

IAEA. Quantification of radionuclide transfer in terrestrial and freshwater environments for radiological assesments. TECDOC-1616; 2009. P. 616 [Vienna].

IAEA. Handbook of parameter values for the prediction of radionuclide transfer in terrestrial and freshwater environments. In: International Atomic Energy Agency, editor. Technical reports series No. 472, Vienna, 2010.

ISO. Guide to the expression of uncertainty in measurment, Geneva, 1993, pp. 101.

Keim RF, Skaugset AE, Weiler M. Storage of water on vegetation under simulated rainfall of varying intensity. Advances in Water Resources 2006; 29: 974-986.

Kinnersley RP, Goddard AJH, Minski MJ, Shaw G. Interception of caesium-contaminated rain by vegetation. Atmospheric Environment 1997; 31: 1137-1145.

Kirchmann H, Fagniart E, van Puymbroeck S. Studies on foliar contamination by radiocaesium and radiostrontium. In: Åberg B, Hungate FP, editors. Radioecological concentration processes, Stockholm, 1967, pp. 475-483.

Kostiainen E, Hänninen R, Rosén K, Haak E, Eriksson A, Nielsen S, Keith-Roach M, Salbu B. Transfer Factors for Nuclear Emergency Preparedness. Report from the NKS/BOK-1.4 project group Countermeasures in Agriculture and Forestry, Roskilde, 2002, pp. 76.

Lehto J, Hou X. Chemistry and analysis of radionuclides Laboratory techniques and methodology. Weinheim: Wiley-VHC Verlag GmbH \& KGaA, 2011.

Lepicard S, Dubreuil GH. Practical improvement of the radiological quality of milk produced by peasant farmers in the territories of Belarus contaminated by the Chernobyl accident - The ETHOS project. Journal of Environmental Radioactivity 2001; 56: 241-253.

Madoz-Escande C, Henner P, Bonhomme T. Foliar contamination of Phaseolus vulgaris with aerosols of Cs137, Sr-85, Ba-133 and Te-123m: influence of plant of plant development stage upon contamination and rain. Journal of Environmental Radioactivity 2004; 73: 49-71.

Marchner P. Marchner's mineral nutrition of higheer plants. London/Waltham, MA: Elsevier/Academic Press; 1986.

Middleton LJ. Absorption and translocation of strontium and caesium by plants from foliar sprays. Nature 1958; 181 : 1300-1303.

Middleton LJ. Radioactive strontium and caesium in the edible parts of crop plants after foliar contamination. International Journal of Radiation Biology and Related Studies in Physics Chemistry and Medicine 1959; 1: $387-$ 402.

Milbourne GM, Taylor R. The contamination of grassland with radio-active strontium. Initial retention and loss. Radiat Bot 1965; 5: 337-347.
Mårtensson A-L. Uppfångning och kvarhållning av 134Cs och $85 \mathrm{Sr}$ i olika växtutvecklingsstadier. Master Uppsala: Department of Soil and Environment, Swedish University of Agricultural Sciences; 2012. p. 67. [In Swedish].

Pröhl G. Interception of dry and wet deposited radionuclides by vegetation. Journal of Environmental Radioactivity 2009; 100: 675-682.

Rosén K. Transfer of radiocaesium in sensitive agricultural environments after the Chernobyl fallout in Sweden .II. Marginal and seminatural areas in the county of Jämtland. Science of the Total Environment 1996; 182: 135-145.

Rosén K, Vinichuk M. Potassium fertilisation and 137Cs transfer from soil to grass and barley in Sweden after the Chernobyl fallout. J. Environ. Radioact. 2014; 130: 2232.

Rosén K, Eriksson A, Haak E. Transfer of radiocaesium in sensitive agricultural environments after the Chernobyl fallout in Sweden .I. County of Gävleborg. Science of the Total Environment 1996; 182: 117-133.

Salbu B. Speciation of Radionuclides in the Environment. In: Meyers RA, editor. Encyclopedia of analytical chemistry: applications, theory and instrumentations. Vol. 14, Nuclear magnetic resonance and electron spin resonance. John Wiley \& Sons Ltd, Chichester, 2000, pp. 1299313016.

Sandsborg J, Wiklert P. Soil physics investigations on four soil profiles. Grundförbättringar 1975/1976; 27: 89-109.

Scotti IA, Carini F. Heavy metal effect on uptake and translocation of Cs-134 and Sr-85 in aubergine plants. Journal of Environmental Radioactivity 2000; 48: 183190.

SMHI. Klimatdata för miljöövervakning. 2012. Swedish Meteorological and Hydrological Institute, Norrköping, 2012.

The R Foundation for Statistical Computing, R, Vienna, 2012.

Tukey HB, Bukovac MJ, Wittwer SH. Absorption of radionuclides by aboveground plant parts and movement within plant. Journal of Agricultural and Food Chemistry 1961; 9: 106-113.

UNSCEAR. Sources of ionizing radiation. Report to the General Assembly, Scientific Annexes A and B. I, New York, 2008.

Vandecasteele CM, Baker S, Forstel H, Muzinsky M, Millan R, Madoz-Escande C, Tormos J, Sauras T, Schulte E, Colle C. Interception, retention and translocation under greenhouse conditions of radiocaesium and radiostrontium from a simulated accidental source. Science of the Total Environment 2001; 278: 199-214.

Wang AZ, Li JZ, Liu JM, Pei TF, Jin CJ. A semi-theoretical model of canopy rainfall interception for Pinus koraiensis Nakai. Ecological Modelling 2005; 184: 355-361.

Yara International ASA. Gödslingsråd Säsongen 2013, 2013, pp. 60. 


\section{Supplementary data 1}

The activity concentration $\left(\mathrm{Bq} \mathrm{kg}^{-1}\right)$ of ${ }^{134} \mathrm{Cs}$ and ${ }^{85} \mathrm{Sr}$ at different harvest occasions after deposition at different growth stages. The means and standard deviation of three replicates $(n=3) . *$ indicates regrowth within the second harvest in the $2^{\text {nd }}$ year (2011) after growth stage 7:7.

\begin{tabular}{|c|c|c|c|c|c|c|c|}
\hline \multirow[t]{2}{*}{ Year } & \multirow[t]{2}{*}{$\begin{array}{l}\text { Growth stage } \\
\text { at deposition }\end{array}$} & \multicolumn{6}{|c|}{$\begin{array}{l}{ }^{134} \mathrm{Cs} \\
\text { Growth stage at sampling }\end{array}$} \\
\hline & & $0: 0$ & $1: 1$ & $2: 2$ & $3: 3$ & $4: 5$ & $5: 6$ \\
\hline \multirow[t]{7}{*}{$1^{\mathrm{st}}$} & $0: 0$ & $3333 \pm 5774$ & $1025 \pm 442$ & $327 \pm 336$ & $21 \pm 12$ & $20 \pm 13$ & $29 \pm 14$ \\
\hline & $1: 1$ & & $4850 \pm 13196$ & $1955 \pm 1731$ & $1331 \pm 1421$ & $99 \pm 8$ & $38 \pm 13$ \\
\hline & $2: 2$ & & & $13822 \pm 1199$ & $3709 \pm 796$ & $138 \pm 43$ & $293 \pm 243$ \\
\hline & $3: 3$ & & & & $31845 \pm 2752$ & $304 \pm 122$ & $211 \pm 71$ \\
\hline & $4: 5$ & & & & & $15800 \pm 4613$ & $14453 \pm 5458$ \\
\hline & $5: 6$ & & & & & & $23133 \pm 7849$ \\
\hline & & $4: 3$ & $6: 5$ & $6: 6$ & $7: 7$ & $3: 6^{*}$ & $6: 7^{*}$ \\
\hline \multirow[t]{8}{*}{$2^{\text {nd }}$} & $4: 3$ & $15333 \pm 1662$ & $5133 \pm 3054$ & $913 \pm 126$ & $866 \pm 116$ & $768 \pm 538$ & $357 \pm 162$ \\
\hline & $6: 5$ & & $19100 \pm 5821$ & $2720 \pm 1485$ & $1733 \pm 339$ & $1321 \pm 588$ & $1086 \pm 586$ \\
\hline & $6: 6$ & & & $19867 \pm 7736$ & $10333 \pm 2538$ & $5723 \pm 1196$ & $3763 \pm 290$ \\
\hline & $7: 7$ & & & & $19100 \pm 3477$ & $6357 \pm 5475$ & $14433 \pm 17645$ \\
\hline & $3: 6^{*}$ & & & & & $42867 \pm 4800$ & $23567 \pm 3951$ \\
\hline & $6: 7 *$ & & & & & & $22967 \pm 8344$ \\
\hline & & $\begin{array}{l}{ }^{85} \mathrm{Sr} \\
\text { Growth stage }\end{array}$ & sampling & & & & \\
\hline & & $0: 0$ & $1: 1$ & $2: 2$ & $3: 3$ & $4: 5$ & $5: 6$ \\
\hline \multirow[t]{7}{*}{$1^{\text {st }}$} & $0: 0$ & $13880 \pm 6317$ & $151 \pm 262$ & $116 \pm 82$ & $252 \pm 146$ & $130 \pm 104$ & $124 \pm 70$ \\
\hline & $1: 1$ & & $21274 \pm 5836$ & $2243 \pm 1295$ & $2366 \pm 2139$ & $232 \pm 153$ & $106 \pm 68$ \\
\hline & $2: 2$ & & & $50973 \pm 6389$ & $7191 \pm 1834$ & $238 \pm 135$ & $594 \pm 316$ \\
\hline & $3: 3$ & & & & $66101 \pm 6872$ & $477 \pm 163$ & $270 \pm 87$ \\
\hline & $4: 5$ & & & & & $287667 \pm 5771$ & $27100 \pm 9875$ \\
\hline & $5: 6$ & & & & & & $48900 \pm 13066$ \\
\hline & & $4: 3$ & $6: 5$ & $6: 6$ & $7: 7$ & $3: 6^{*}$ & $6: 7 *$ \\
\hline \multirow[t]{6}{*}{$2^{\text {nd }}$} & $4: 3$ & $16300 \pm 1735$ & $3044 \pm 2021$ & $465 \pm 136$ & $212 \pm 59$ & $440 \pm 317$ & $199 \pm 62$ \\
\hline & $6: 5$ & & $20967 \pm 5490$ & $1960 \pm 1247$ & $1090 \pm 401$ & $927 \pm 540$ & $602 \pm 359$ \\
\hline & $6: 6$ & & & $20800 \pm 7227$ & $9787 \pm 2707$ & $5593 \pm 941$ & $3580 \pm 875$ \\
\hline & $7: 7$ & & & & $20233 \pm 3564$ & $5941 \pm 5189$ & $15213 \pm 19408$ \\
\hline & $3: 6^{*}$ & & & & & $43700 \pm 5333$ & $24733 \pm 3513$ \\
\hline & $6: 7 *$ & & & & & & $29600 \pm 10227$ \\
\hline
\end{tabular}




\section{Supplementary data 2}

Selected linear regression models for estimating activity concentration in the two crops $\left({ }^{134} \mathrm{Cs}\right.$ interception fraction vs. ${ }^{85} \mathrm{Sr}$ interception fraction), see table 3 . In the $1^{\text {st }}$ year, a much higher amount of ${ }^{85} \mathrm{Sr}$ was deposited than that of ${ }^{134} \mathrm{Cs}$. In the $2^{\text {nd }}$ year, the amounts of both radionuclides were more or less the same (see table 1). (--) represents the 1:1 line.

\section{1st year}

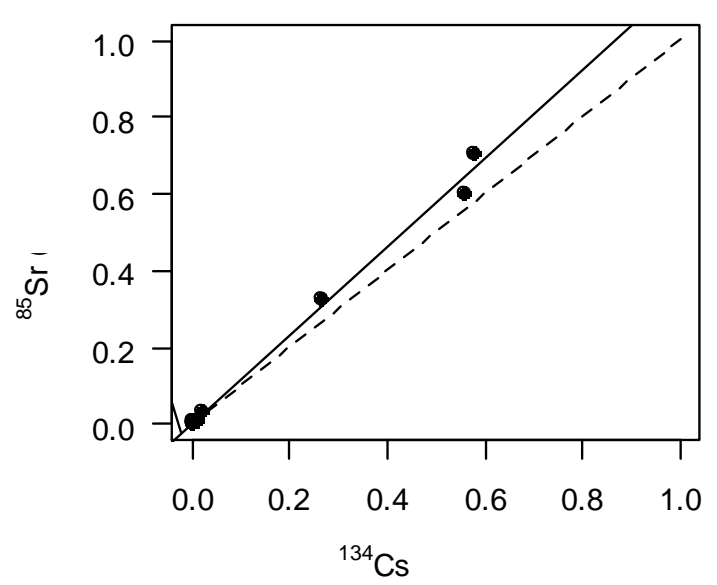

2nd year

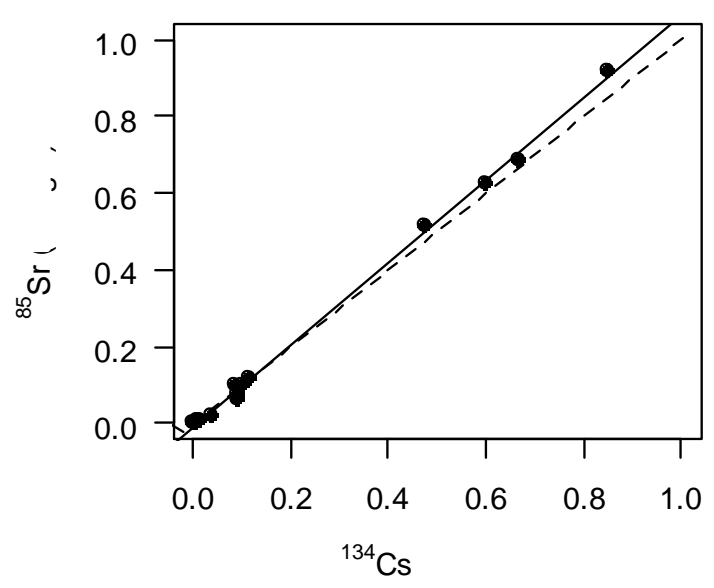

